\title{
3. ANALYSIS OF TRACE ELEMENTS IN BASALTS BY SHIPBOARD X-RAY FLUORESCENCE SPECTROMETRY: A DISCUSSION OF NIOBIUM ${ }^{1}$
}

\author{
J. Etoubleau and H. Bougault, Centre National pour l'Exploitation des Océans, Centre Océanologique de Bretagne \\ M. Rideout, Graduate School of Oceanography, University of Rhode Island \\ J. Brannon, Department of Earth and Planetary Sciences, Washington University \\ and \\ B. Weaver, Department of Geology, University of Leicester ${ }^{2}$
}

\begin{abstract}
X-ray fluorescence spectrometry was used on board the Glomar Challenger during Leg 82 for analysis of "hygromagmaphile" trace elements that are useful to identify so-called "depleted" or "enriched" basalts; the results were used in choosing the new sites to be drilled on the basis of the "enriched" or "depleted" character of previous sites. This chapter describes a hitherto unpublished method for deducing concentrations from intensity measurements; the method yielded the precision (better than $1 \mathrm{ppm}$ for $\mathrm{Nb}$ ) necessary for purposes of the cruise.

The procedure for the matrix-effect correction is described. The case of $\mathrm{Nb}$ is discussed in detail because $\mathrm{Nb}$ concentrations in basalts are the lowest among the elements investigated $(\mathrm{Nb}, \mathrm{Zr}, \mathrm{Ti}, \mathrm{Y}, \mathrm{V})$ and because it is the key element for deducing the enriched or depleted character of the different basalt units. Ta neutron-activation measurements made on shore after the cruise demonstrate, on the basis of the well-known constant $\mathrm{Nb} / \mathrm{Ta}$ ratio in basalts, that the accuracy of the shipboard measurements of $\mathrm{Nb}$ concentrations in basalt units is about $0.5 \mathrm{ppm}$.
\end{abstract}

\section{INTRODUCTION}

Nine years after the first experimental X-ray Fluorescence (XRF) chemical analysis of rocks on board a research vessel during the GIBRACO cruise of the Jean Charcot (Bougault and Cambon, 1973), the XRF van provided by $\mathrm{CNEXO}^{3}$ was successfully used during DSDP Leg 82. Before that cruise, the XRF van had been used 12 times on board the Glomar Challenger since 1974 (Leg 37). On these earlier legs, the analyses were performed mainly to obtain the best descriptions of the different basalt units, based on major-element compositions and petrographic descriptions; these descriptions were then used as a guide in sampling for shore-based studies. The equipment, analytical procedures, and calculations used to derive major-element concentrations were described in Initial Reports Volumes 37 (Bougault, 1977); (Bougault, Treuil, et al., 1979; Natland et al., 1979); and 65 (Cambon et al., 1983). During some of these cruises (Legs 45, 55, 65, 69), the concentrations of some trace elements $(\mathrm{Ni}, \mathrm{Sr}, \mathrm{Zr}$ ) were also measured to aid in describing the basalt units.

For Leg 82 , as the cruise progressed, we had to select each site from a grid of 11 potential locations that were

\footnotetext{
${ }^{1}$ Bougault, H., Cande, S. C., et al., Init. Repts. DSDP, 82: Washington (U.S. Govt. Printing Office)

2 Addresses: (Etoubleau and Bougault, present address) IFREMER (formerly CNEXO), Centre de Brest, B. P. 337, 29273 Brest Cedex, France; (Rideout, present address) Department of Geology, Rice University, P.O. Box 1892, Houston, Texas 77251; (Brannon) Department of Earth and Planetary Sciences, Washington University, St. Louis, Missouri 63130; (Weaver. present address) School of Geology and Geophysics, University of Oklahoma, Norman, Oklahoma 73019.

${ }^{3}$ The XRF van was built with funds from a program sponsored by Centre National pour I'Exploitation des Océans (CNEXO), Centre National de la Recherche Scientifique, Délegation Générale à la Recherche Scientifique et Technique, and the "Ministère des Universités" to promote chemical analysis on board oceanographic research vessels.
}

chosen ahead of time according to the objectives of the cruise: to examine mantle heterogeneity in the Azores Triple Junction area, away from the ridge axis, and along isochrons (see "Background and Objectives," this volume). The elements that can give information about mantle heterogeneity and that can be measured on board by $\mathrm{X}$-ray fluorescence spectrometry are niobium, zirconium, titanium, yttrium, and vanadium. The behavior of each of these "hygromagmaphile" trace elements mimics that of a different rare earth element (REE). For example, $\mathrm{Nb}$ behaves like $\mathrm{La}$ (the lightest REE), and $\mathrm{Zr}$ behaves like Sm (an REE of medium atomic number); consequently, the ratio $\mathrm{Nb} / \mathrm{Zr}$ can be used in place of $\mathrm{La} / \mathrm{Sm}$ to determine the depleted or enriched character of the basalts (Schilling and Winchester, 1967; Bougault et al., this volume). Expressed in their most convenient form (normalized to chondrite), the ratios are nearly equal; that is, $(\mathrm{Nb} / \mathrm{Zr})_{\mathrm{ch}}$ is about equal to $(\mathrm{La} / \mathrm{Sm})_{\mathrm{ch}}$. Thus, in addition to providing data for the best descriptions of basalt units through major-element and some trace-element abundances, the main objective of on-board XRF analyses during Leg 82 was to determine concentrations of those "hygromagmaphile" trace elements, which could be used as a basis for site selection consistent with the objectives of the cruise.

The concentrations of the pertinent hygromagmaphile elements are of the following orders of magnitude: $\mathrm{Nb}$, $0-50 \mathrm{ppm}$, with a critical range of values for geochemical interpretation between 0 and $15 \mathrm{ppm} ; \mathrm{Zr}, 50-200 \mathrm{ppm}$ ); $\mathrm{Ti}, 3000-15,000 \mathrm{ppm}$ (the abundance of this element is obtained from the major-minor analytical procedure); Y, $15-45 \mathrm{ppm}$; and V, 150-450 ppm. From these ranges of concentrations, it is clear that $\mathrm{Nb}$ is the most critical element. We will examine and determine the accuracy 
and limits of detection through the statistics of counting rates, possible interferences, the matrix-effect correction that we have used, and standard concentrations.

\section{MATRIX EFFECT}

The relationship between the concentration $c$ and the intensity $I$ emitted by an element in a sample irradiated by $\mathrm{X}$ rays is

$$
I=\frac{\mathrm{A} c}{M},
$$

where $\mathrm{A}$ is a constant and $M$ the matrix effect. Usually, for a simple geometry of the spectrometer, the matrix effect $M$ can be formulated by

$$
M=\Sigma(\mu / \rho)_{p i} c_{i}+\Sigma(\mu / \rho)_{z i} c_{i},
$$

where $c_{i}$ is the concentration of an element $i,(\mu / \rho)_{p i}$ the coefficient of absorption of the primary excitating beam by the element $i$, and $(\mu / \rho)_{z i}$ the coefficient of absorption of the emitted beam (wavelength $\lambda_{z}$ ) by the element $i$.

It is difficult in trace-element analysis to use a "buffer" glass disc, such as is used in major-element analysis; such a method would increase $M$ (relative to the numerator in Eq. [1]) and thus diminish $I$, the sensitivity, and the limit of detection. As far as possible, for trace elements, the measurements have to be done on the rock powders themselves. The rocks are crushed in an agate mortar, and the powder is pressed into a pellet, using wax as a binder. This method of preparation, which is employed to obtain the best counting rate, limits the possibilities of contamination, and is simple and quick to use on board the ship. The same pellets can then be used on shore, either to verify on-board measurements or for additional determinations. But, because the matrix effect can vary by as much as a factor of 2 , it is necessary to have a precise method of either calculating or measuring $M$, in order to calculate accurate concentrations of trace elements.

Among the three main methods that permit access to the value of the matrix effect are (1) use of standards that have the same major-element compositions as unknown samples; (2) measurement of the background or Compton peak (Anderman and Kemp, 1958; Champion et al., 1960; Clark and Mitchell, 1972; Cullen, 1962; Delong and McCullough, 1973; Feather and Willis, 1976; Hower, 1959; Hutton and Norrish, 1977; Johnson and Stout, 1958; Kalman and Heller, 1962; Leoni and Saitta, 1977; Nesbitt et al., 1976; Price and Angell, 1968; Reynolds, 1963, 1967; Sherman, 1955; Verdumen, 1977; Walker, 1973; Weber and Newbury, 1971; Wilband, 1975; Wyrobish, 1977); and (3) calculation of $M$ from the major-element composition of each sample.

We chose the third one, because the major-element compositions had to be determined on board to be useful in preparing the best descriptions of the different basalt units. Nevertheless, we still have to prove that this method is practicable and attains the necessary precision.
The matrix effect is the sum of two terms (Eq. [2]), one related to the primary excitating X-ray beam and the other to the beam emitted by the studied element in the sample, provided that the parameters accounting for the geometry of the instrument are integrated into the constant $A$ in Equation (1).

When we know the wavelength of the beam absorbed by the sample, it is easy to find $\mu / \rho$ from a table of mass-absorption coefficients. This coefficient $(\mu / \rho)_{z i}$, is straightforward for the emitted beam, because by definition its wavelength, $\lambda_{z}$, is known. But finding $(\mu / \rho)_{p i}$, corresponding to the excitating beam is much more difficult, because that beam is polychromatic; this is the classic problem of finding the "equivalent" wavelength that would induce the same fluorescence intensity as the polychromatic beam from the X-ray tube. We want to show that, in general, knowledge of the equivalent wavelength is not necessary for calculating the matrix effect from the major-element concentrations.

$\lambda_{z}$ is the wavelength of $\mathrm{X}$ rays emitted by the element of atomic number $z . \lambda_{A E}$ is the absorption edge of this element. For rock samples, the trace elements can be classified into two groups according to the value of $\lambda_{z}$ or $\lambda_{A E}$ with respect to Fe $K_{A E}$ (Hower, 1959; Quintin, 1970; Reynolds, 1963); $\mathrm{Fe}$ is the major element with the highest atomic number:

1. $\lambda_{A E}$ is higher than Fe $K_{A E}$ : The pertinent elements for silicate rock samples are $\mathrm{Sc}, \mathrm{V}, \mathrm{Cr}$, and $\mathrm{Co}$.

2. $\lambda_{z}$ is shorter than $\mathrm{Fe} K_{A E}$ : This is the general case if a $K$ line can be excited.

In the second general case, the range of wavelengths that permit excitation of an element is necessarily out of the range of absorption discontinuities of major elements (Fig. 1). A trace element whose atomic number $z$ is higher than 27 has a $K$ absorption edge lower than $\mathrm{Fe}$ $K_{A E}$ : the photons able to excitate this element have wavelengths shorter than $\lambda_{A E}$. Under these conditions, whatever the equivalent wavelength $\lambda_{p}$, the mass-absorption

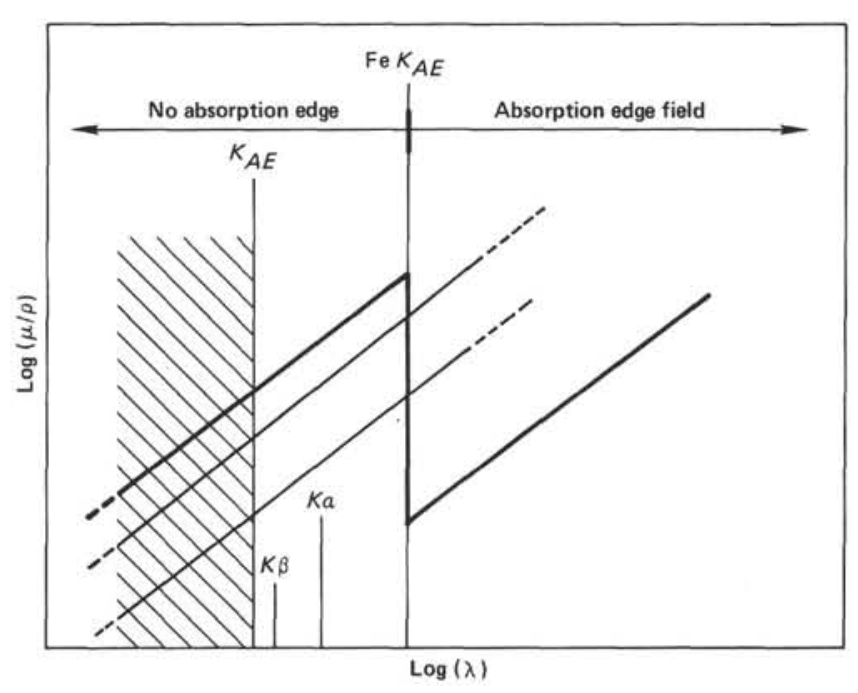

Figure 1. Range of absorption edges for trace elements, referred to $\mathrm{Fe}$ $K_{A E}$ (Fe being the major element with the highest atomic number). See text for discussion. 
coefficient of the major element $i$ with respect to the primary excitating beam can be written as

$$
(\mu / \rho)_{p i}=\delta_{i}\left(\lambda_{z}\right)^{\gamma} .
$$

This is the classic equation that shows the relationship between mass-absorption and wavelength; $\delta_{i}$ is characteristic of the absorbing element and $\gamma$ is a constant.

From Equation (2), the matrix effect $M$, which is a function of the primary beam (wavelength $\lambda_{p}$ ), the emitted $X$ rays (wavelength $\lambda_{z}$ ), and the major elements $(i)$ can be written as

$$
\begin{aligned}
& M\left(\lambda_{p}, \lambda_{z}, i\right)=\left(\lambda_{p}\right)^{\gamma} \Sigma \delta_{i} c_{i}+\left(\lambda_{z}\right)^{\gamma} \Sigma \delta_{i} c_{i}, \text { or } \\
& M\left(\lambda_{p}, \lambda_{z}, i\right)=\left[\left(\lambda_{p}\right)^{\gamma}+\left(\lambda_{z}\right)^{\gamma}\right] \Sigma \delta_{i} c_{i} .
\end{aligned}
$$

Whatever the value of the equivalent wavelength $\lambda_{p}$, we can write $\left(\lambda_{p}\right)^{\gamma}=K\left(\lambda_{z}\right)^{\gamma}$ and deduce that

$$
M\left(\lambda_{p}, \lambda_{z}, i\right)=(1+K)\left(\lambda_{z}\right)^{\gamma} \Sigma \delta_{i} c_{i}=M\left(\lambda_{z}, i\right) .
$$

This result can be expressed as follows: For a trace element whose emitted $\mathrm{X}$ rays are of a wavelength shorter than the absorption edge of the major element with the highest atomic number in the studied sample, the matrix effect is independent of the primary excitation X rays.

If a trace element $z^{\prime}$ meets the same requirement as $z$, it is also possible to write

$$
\left(\lambda_{z^{\prime}}\right)^{\gamma}=K^{\prime}\left(\lambda_{z}\right)^{\gamma} .
$$

This observation permits us to deduce that

$$
M\left(\lambda_{z^{\prime}}, i\right)=K^{\prime}(1+K)\left(\lambda_{z}\right)^{\gamma \Sigma \Sigma \delta_{i}} c_{i} .
$$

This relationship can be expressed in the following way: For two trace elements $z$ and $z^{\prime}$ whose emitted $\mathrm{X}$ rays are of a wavelength shorter than the absorption edge of the major element with the highest atomic number in the studied sample, the ratio of the matrix effect for $z^{\prime}$ to the matrix effect for $z$ is a constant.

With the conditions that have been given here for a trace element, the calculation of the matrix effect is thus, except for a constant, independent of the wavelength of the studied trace element. We note that that constant need not be known, because the constant $\mathrm{A}$ in Equation (1) has to be determined anyway, and the constant $K^{\prime}(1$ $+K)\left(\lambda_{z}\right)^{\gamma}$ can be implicitly included in A during the standardization procedure.

It is now possible to account for a second relationship between the mass-absorption coefficients and atomic numbers of the absorbing elements (the major elements in the sample):

$$
(\mu / \rho)_{i}=\beta\left(z_{i}\right)^{\alpha},
$$

where $z_{i}$ is the atomic number of the absorbing major element $i$ and $\alpha$ and $\beta$ are constants.
With this relationship, it is easy to deduce that

$$
\mathrm{I}=\frac{\mathrm{A} c}{M}=\frac{\mathrm{A} c}{\Sigma \beta\left(\mathrm{z}_{i}\right)^{\alpha} c_{i}}=\frac{\mathrm{A} c}{\beta \Sigma\left(\mathrm{z}_{i}\right)^{\alpha} c_{i}} .
$$

$\beta$ is included in the constant $A$ during standardization:

$$
I=\frac{\mathrm{A} c}{\Sigma\left(z_{i}\right)^{\alpha} c_{i}} .
$$

This is the simple general relationship that exists between the intensity of $\mathrm{X}$ rays emitted by a trace element under the conditions mentioned, its concentration, and the matrix effect of the sample. In particular, this relationship applies for $K$ emissions of trace elements in rocks whose atomic numbers are higher than 27 , such as $\mathrm{Nb}, \mathrm{Zr}$, and $\mathrm{Y}$. The concentrations of these elements were calculated during Leg 82 by using Equation (10).

The value of the constant $\alpha$ can be determined from tables of mass-absorption coefficients (Leroux and Thin, 1977). Different values of $\alpha$, given in different tables, do not produce significant differences in the results for a wide range of rock compositions. An example is given in Table 1, where $\mathrm{Rb}$ and $\mathrm{Nb}$ concentrations have been calculated using $\alpha$ values of 2.65 and 2.81 .

\section{SHIPBOARD TRACE-ELEMENT ANALYSIS DURING LEG 82: A SPECIFIC APPROACH FOR NIOBIUM}

For $K$ emissions, the theoretical precision of determinations of trace-element concentrations is about $1 \mathrm{ppm}$. Even if there are other parameters to account for in determinating concentrations, such as instrumental interferences (Bougault et al., 1977) and spectral interferences (e.g., Y and V), the precision obtained is not generally critical for geochemical interpretation if the concentrations are higher than 20 or $30 \mathrm{ppm}$. An example is provided by Y, where the $\mathrm{Rb} K_{\beta}$ line interferes with the Y $K_{\alpha}$ line. The results are given in Table 2. A general relationship accounting for instrumental and spectral interference $\left(\mathrm{Rb} K_{\beta}\right)$ has been used:

$$
\left(I-I_{0}\right) M=\mathrm{A} c+\mathrm{A}^{\prime} c^{\prime}+B,
$$

where

$I \quad=$ net intensity,

$I_{0}$ and $B=$ two parameters for instrumental interferences,

$A \quad=$ sensitivity for the studied element,

$A^{\prime} \quad=$ sensitivity for the interfering element,

$c$ and $c^{\prime}=$ the concentrations of the studied element and the interfering element, respectively.

From Figure 2 and the calculated $\mathrm{Y}$ concentrations in Table 2, it appears that the precision of about $1 \mathrm{ppm}$ is not critical for geochemical interpretations for concentrations in basalts that range between 20 and $50 \mathrm{ppm}$. 
Table 1. Influence of the choice of the value of $\alpha$ on the calibration (concentrations in ppm).

\begin{tabular}{|c|c|c|c|c|c|c|}
\hline \multirow[b]{3}{*}{ Standard } & \multicolumn{3}{|c|}{$\mathrm{Rb}$ concentration } & \multicolumn{3}{|c|}{$\mathrm{Nb}$ concentration } \\
\hline & \multirow[b]{2}{*}{ Recommended } & \multicolumn{2}{|c|}{ Calculated } & \multirow[b]{2}{*}{ Proposed } & \multicolumn{2}{|c|}{ Calculated } \\
\hline & & $(\alpha=2.65)$ & $(\alpha=2.81)$ & & $(\alpha=2.65)$ & $(\alpha=2.81)$ \\
\hline $\mathrm{AGV}_{1}$ & 67 & 67.2 & 67.9 & 15.0 & 14.6 & 14.7 \\
\hline BR & 45 & 45.2 & 44.8 & 114 & 114 & 115 \\
\hline $\mathrm{BCR}_{1}$ & 46 & 46.6 & 46.5 & 14.5 & 14.9 & 14.2 \\
\hline W1 & 21 & 21.8 & 20.9 & 8.5 & 9.0 & 8.3 \\
\hline DTS $_{1}$ & 0 & -0.6 & -1.2 & 0.0 & 0.0 & 0.3 \\
\hline $\mathrm{G}_{2}$ & 169 & 170.0 & 171.0 & 11.0 & 10.1 & 10.7 \\
\hline $\mathrm{GSP}_{1}$ & 254 & 253.0 & 255.0 & & & \\
\hline $\mathrm{PCC}_{1}$ & 0 & 0.1 & -0.4 & 0.0 & 0.8 & 1.4 \\
\hline DRN & 75 & 73.2 & 74.2 & 9.0 & 8.2 & 7.9 \\
\hline $\mathrm{GH}$ & 390 & 390.0 & 389.0 & 85.0 & 85.0 & 84.0 \\
\hline GA & & & & 11.0 & 11.1 & 11.6 \\
\hline$r^{2}$ & & 0.99994 & 0.99993 & & 0.99979 & 0.99963 \\
\hline$\sigma$ & & 0.33 & 0.34 & & 0.19 & 0.25 \\
\hline
\end{tabular}

Note: $\mathrm{Rb}$ and $\mathrm{Nb}$ concentrations have been calculated using $\alpha$ values of 2.65 and 2.81 (see text). "Recommended" and "proposed" have the usual meanings as applied to concentrations for standards. A recommended value has a higher probability of being close to the true value than a proposed value. $r^{2}=$ the correlation coefficient and $\sigma=$ the standard deviation in ppm.

Table 2. Niobium: net intensities, matrix-effect values $(M)$, and recommended and calculated concentrations of standards.

\begin{tabular}{lrcrr}
\hline $\begin{array}{c}\text { Hole-Core-Section } \\
\text { (interval in cm) }\end{array}$ & Intensity & $M$ & $\begin{array}{r}\text { Nb conc. } \\
\text { 16Ta } \\
\text { (ppm) }\end{array}$ & $\begin{array}{c}\text { Nb. conc. } \\
\text { (calculated) } \\
\text { (ppm) }\end{array}$ \\
\hline Leg 55 & & & & \\
& & & & \\
433C-10-4, 118-121 & 4160 & 122.08 & 6.9 & 5.9 \\
433C-10-2, 58-60 & 8739 & 126.30 & 12.5 & 12.5 \\
433C-14-3, 55-57 & 10,969 & 125.29 & 15.5 & 15.4 \\
433C-32-1, 98-101 & 2914 & 117.69 & 4.3 & 4.1 \\
Leg 69 & & & & \\
& & & & \\
504B-19-2, 46-49 & 8091 & 112.93 & 9.9 & 10.4 \\
504B-19-1, 73-77 & 10,664 & 114.47 & 13.6 & 13.8 \\
504B-4-2, 52-58 & 116 & 115.40 & 0.3 & 0.5 \\
Leg 70 & & & & \\
504B-56-1, 139-142 & 1825 & 118.50 & 2.6 & 2.7 \\
Leg 65 & & & & \\
482D-10-3, 101-103 & 683 & 118.97 & 1.4 & 1.2 \\
483-26-1, 128-130 & 2720 & 121.70 & 3.5 & 4.0 \\
\hline
\end{tabular}

Note: $I M=A C+B ; A=90,954.29 ; B=-30,708.25$. (See text for discussion.) Tube, Au; counter, NaI; crystal, LIF; collimator, $0^{\circ} 15$; background counting time, $4 \times 40 \mathrm{~s}$; peak counting time, $4 \times 40 \mathrm{~s}$; peak, $21^{\circ} 34^{\prime}$; left background, $20^{\circ} 94^{\prime}$; right background, $21^{\circ} 72^{\prime}$.

Another example is given by $\mathrm{V}$. There is a spectral interference with the Ti $K_{\beta}$ line, Ti being a minor element, and even if $\mathrm{V}$ does not meet the theoretical requirements previously mentioned as regards $K$ absorption edge versus Fe $K_{A E}$ (we will not discuss the specific method used), the precision obtained at the end is comparable to that obtained for Y (Table 3, Fig. 3).

The examples of $\mathrm{Y}$ and $\mathrm{V}$ show that even when spectral interferences exist it is possible to attain a convenient accuracy, if the concentrations of the elements are higher than about $20 \mathrm{ppm}$. In the case of $\mathrm{Nb}$, a specific problem exists for a range of concentrations between 0 and $15 \mathrm{ppm}$. In this range of concentrations, two addi-

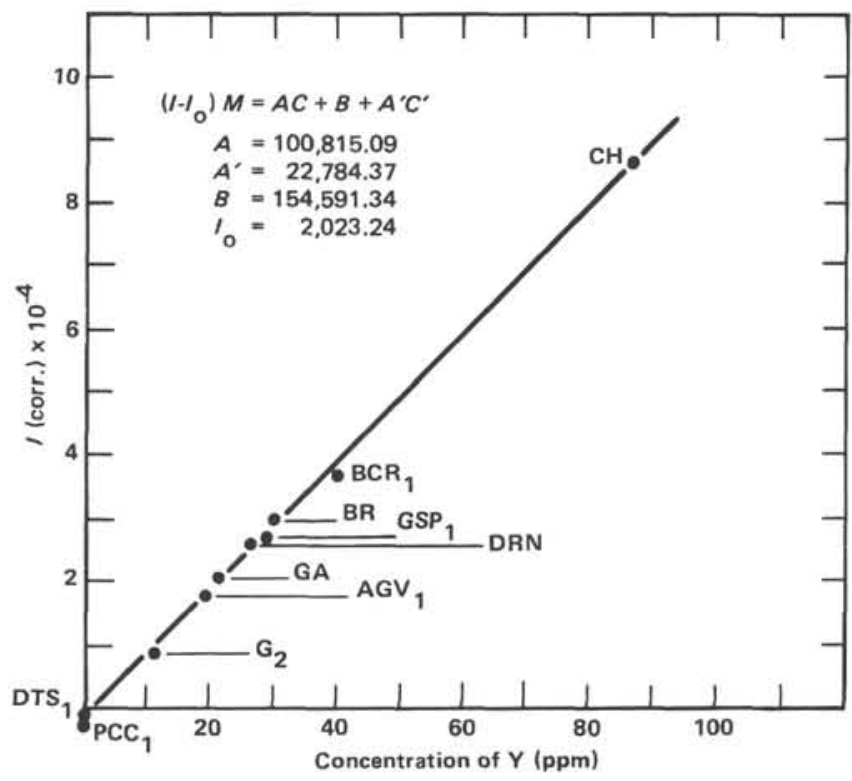

Figure 2. Y calibration curve. Intensities (corrected for matrix effects) versus concentrations. The parameters $A, A^{\prime}, B$, and $I_{0}$ are discussed in text. Data points correspond to geologic standards listed in Table 3. Corr. = corrected.

tional factors must be considered to avoid systematic errors that could be larger than the precision related to counting statistics. The first concerns the settings of the spectrometer (peak and background positions), and the second relates to knowledge of recommended concentrations of standards.

The setting of the spectrometer requires careful selection of peak and background positions to obtain a zero net intensity (peak minus background) for a blank (pure quartz, for instance). This zero intensity for zero concentration of $\mathrm{Nb}$ must then be checked in relation to the second factor (knowledge of standards) for a natural sample; this is to minimize possible interference with the tail of the Y $K_{\beta}$ peak. 
Table 3. Yttrium: net intensities, matrix-effect values $(M)$, and recommended and calculated concentrations of standards.

\begin{tabular}{|c|c|c|c|c|c|}
\hline Standard & Intensity & $M$ & $\begin{array}{l}\text { Recommended } \\
\text { concentration } \\
\text { (ppm) } \\
\mathrm{Y}\end{array}$ & $\begin{array}{l}\text { Recommended } \\
\text { concentration } \\
\text { (ppm) } \\
\text { Rb }\end{array}$ & $\begin{array}{c}\text { Calculated } \\
\text { concentration } \\
\text { (ppm) } \\
\text { Y }\end{array}$ \\
\hline GH & 23,5349 & 75.08 & 87 & 390 & 87.2 \\
\hline GA & 76,369 & 81.94 & 21 & 176 & 22.2 \\
\hline $\mathrm{PCC}_{1}$ & -721 & 88.25 & 0 & 0 & -0.9 \\
\hline DRN & 41,542 & 109.3 & 26 & 75 & 27.4 \\
\hline BR & 32,378 & 131.38 & 30 & 45 & 30.9 \\
\hline $\mathrm{BCR}_{1}$ & 40,119 & 124.98 & 40 & 47 & 38.1 \\
\hline $\mathrm{AGV}_{1}$ & 35,409 & 98.71 & 19 & 67 & 19.1 \\
\hline $\mathrm{GSP}_{1}$ & 97,384 & 89.00 & 29 & 254 & 28.3 \\
\hline $\mathrm{G}_{2}$ & 60,217 & 81.31 & 11 & 170 & 10.0 \\
\hline DTS $_{1}$ & 979 & 90.26 & 0 & 0 & 0.6 \\
\hline
\end{tabular}

Note: $\left(I-I_{0}\right) M=A C+A^{\prime} C^{\prime}+B . A=100,815.09 ; A^{\prime}=22,784.37 ; B=$ 154,591.34; $I_{0}=2023.24$. (See text for discussion.) Tube, Au; counter, Nal; crystal, LIF; collimator, $0^{\circ} 15$; background counting time, $100 \mathrm{~s}$; peak counting time, $2 \times 100 \mathrm{~s}$; peak, $23^{\circ} 73^{\prime}$; left background, $23^{\circ} 42^{\prime}$; right background, $24^{\circ} 08^{\prime}$.

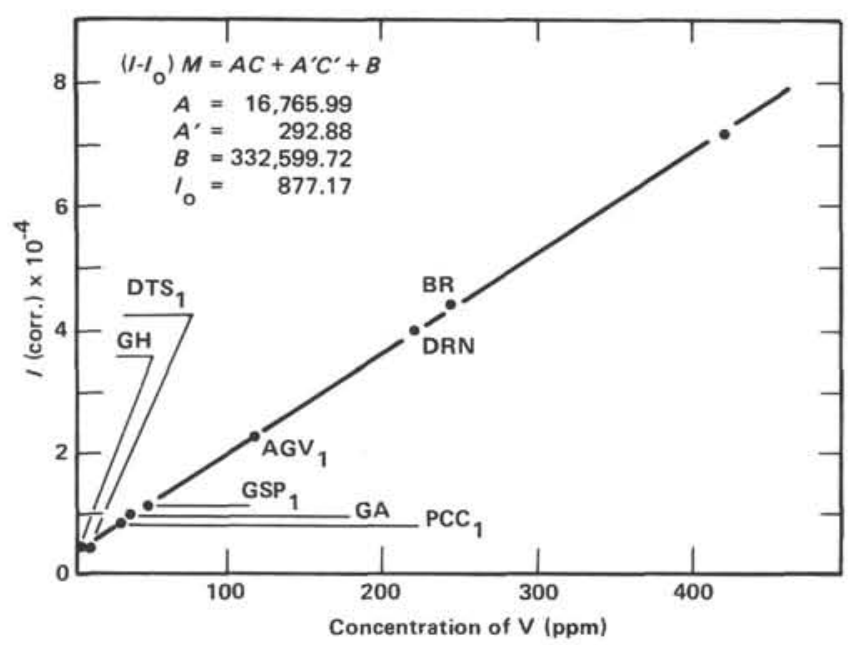

Figure 3. V calibration curve. Intensities (corrected for matrix effects) versus concentrations. The parameters $A, A^{\prime}, B$, and $I_{0}$ are discussed in text. Data points correspond to geologic standards listed in Table 4.

For $\mathrm{Nb}$ concentrations of standards, according to the last review of trace elements in rocks by Abbey (1980), no recommended $\mathrm{Nb}$ concentrations exist between 0 and $15 \mathrm{ppm}$, and there are none for higher concentrations, either; all values are "proposed" concentrations. The good fit in Table 1 between "proposed" concentrations and concentrations found with either $\alpha=2.65$ or $\alpha=$ 2.81 demonstrates the coherence of the analytical method between 0 and $115 \mathrm{ppm}$. For these international standards, one observes that two of them are close to zero concentration, five are between 8 and $15 \mathrm{ppm}$, and the last two are between 85 and $114 \mathrm{ppm}$. Such a distribution of $\mathrm{Nb}$ concentrations in standards does not preclude a constant error of between 0 and $15 \mathrm{ppm}$, particularly if we keep in mind that the values in Table 1 are only "proposed."

To overcome the absence of well-known certified standards for $\mathrm{Nb}$ between 0 and $15 \mathrm{ppm}$, we will use the geochemical properties of the pair of elements $\mathrm{Nb}$ and $\mathrm{Ta}$. A large number of samples, many of them DSDP samples, have been studied for these two elements. $\mathrm{Nb}$ con- centrations were determined by XRF spectrometry using the calibration corresponding to values proposed in Table 1 (Bougault, 1980). Ta concentrations were measured through instrumental neutron activation analysis (INAA), using cadmium vials (Jaffrezic et al., 1977). These results demonstrate that the $\mathrm{Nb} / \mathrm{Ta}$ ratio is constant in mid-ocean ridge basalts, from "depleted" to "enriched" types according to the "rare earths" definition (Bougault, Joron, et al., 1979). Since that last-mentioned study, the $\mathrm{Nb} / \mathrm{Ta}$ value of 16 has been confirmed by analysis of several other samples from different geologic environments: seamounts in the North Pacific (Leg 55: Cambon et al., 1980) and volcanoes of "la chaîne des Puys" (El Azzouzi, 1981; El Azzouzi et al., 1982). The accuracy of Ta measurements by INAA, especially for low values, is much better than the accuracy of $\mathrm{Nb}$ determinations by XRF spectrometry. From these observations (constant $\mathrm{Nb} / \mathrm{Ta}$ ratio in basalts and accuracies of $\mathrm{Nb}$ and $\mathrm{Ta}$ measurements), we were able to detect a systematic $\mathrm{Nb}$ overestimate of about $1 \mathrm{ppm}$ for the lowest concentrations (between 0 and about $6 \mathrm{ppm}$ ). Taking this into account, it was possible to demonstrate that the constant $\mathrm{Nb} / \mathrm{Ta}$ ratio in the most "depleted" basalts (Leg 65 and Legs 69 and 70, Hole 504B) is preserved (Cambon et al., 1983; Etoubleau et al., 1983), as shown in Figure 4. For Leg 82, we thus selected our own standards, whose $\mathrm{Nb}$ and $\mathrm{Ta}$ concentrations are well distributed ( 0 to $15 \mathrm{ppm}$ for $\mathrm{Nb}$; 0 to $1 \mathrm{ppm}$ for $\mathrm{Ta}$ ). Because the Ta accuracy is better than the $\mathrm{Nb}$ accuracy and the $\mathrm{Nb} / \mathrm{Ta}$ ratio is constant in basalt rocks, we chose the $\mathrm{Nb}$ concentrations of selected standards to be 16 times the Ta concentrations; this was a better approximation to the true $\mathrm{Nb}$ concentrations than could be obtained through $\mathrm{Nb}$ measurements themselves.

We thus come to a set of standards of basalts whose $\mathrm{Nb}$ concentrations are between 0 and $15 \mathrm{ppm}$. The determination of these concentrations is based both on the determination from international standards and on the

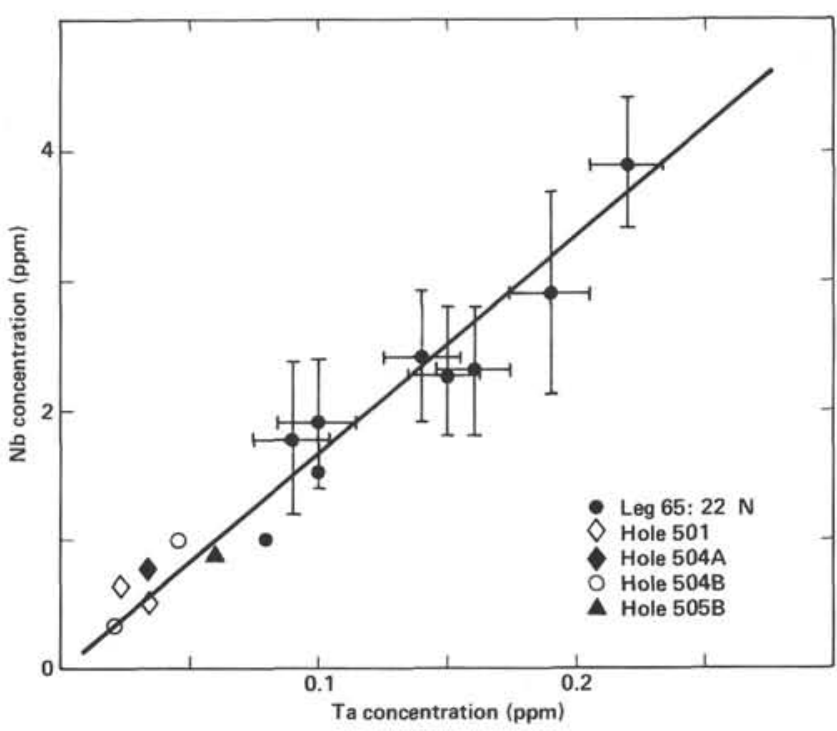

Figure 4. $\mathrm{Nb}$ versus Ta concentrations. Filled circles correspond to the different basalt units encountered at $22^{\circ} \mathrm{N}$ on the East Pacific Rise during Leg 65; other symbols identified in key to figure. 
constant $\mathrm{Nb} / \mathrm{Ta}$ ratio in basalts. Some uncertainties can remain for true concentrations, but because $\mathrm{Ta}$ is determined with better precision than $\mathrm{Nb}$, we are sure to have a correct classification (concentrations relative to each other).

In addition to this approach to developing standards with well-known $\mathrm{Nb}$ concentrations, the proposed method presents the two following advantages:

1. Even if the matrix effect is well calculated, as demonstrated by Table 1 for $\mathrm{Rb}$ and $\mathrm{Nb}$, this method uses known basalt standards, which reduce the range of variation of the matrix effect; it varies here by about $10 \%$, whereas it varies by a factor of 2 for the usual standards mentioned in Table 1.

2. A possible spectral interference, like the $\mathrm{Y} K_{\beta}$ line, should not be critical in this method when the same rock types are considered for standardization.

The calibration curves obtained on board are presented in Figures 5 and 6: net intensity versus $\mathrm{Nb}$ concentrations and matrix-effect-corrected intensity versus concentration, respectively. The standard deviations, indicated on each figure, demonstrate the efficiency of matrix-effect correction even within a narrow range of rock compositions. Net intensities and $\mathrm{Nb}$ concentrations of standards found from the calibration are indicated in Table 4; they correspond to a single measurement run. Instrumental settings and conditions of measurements are also mentioned in the footnote to Table 4 .

The standard $\mathrm{BR}$, whose proposed $\mathrm{Nb}$ concentration is $114 \mathrm{ppm}$, was used to check to stability of the instrument during Leg 82 . The calculated $\mathrm{Nb}$ concentration from the parameters obtained by the calibration in Figure 6 (whose range is $0-15 \mathrm{ppm}$ ) was found to be $115 \mathrm{ppm}$. This value is in agreement with the values presented in Table 1 and is a guarantee of self-consistency between high and low $\mathrm{Nb}$ concentrations.

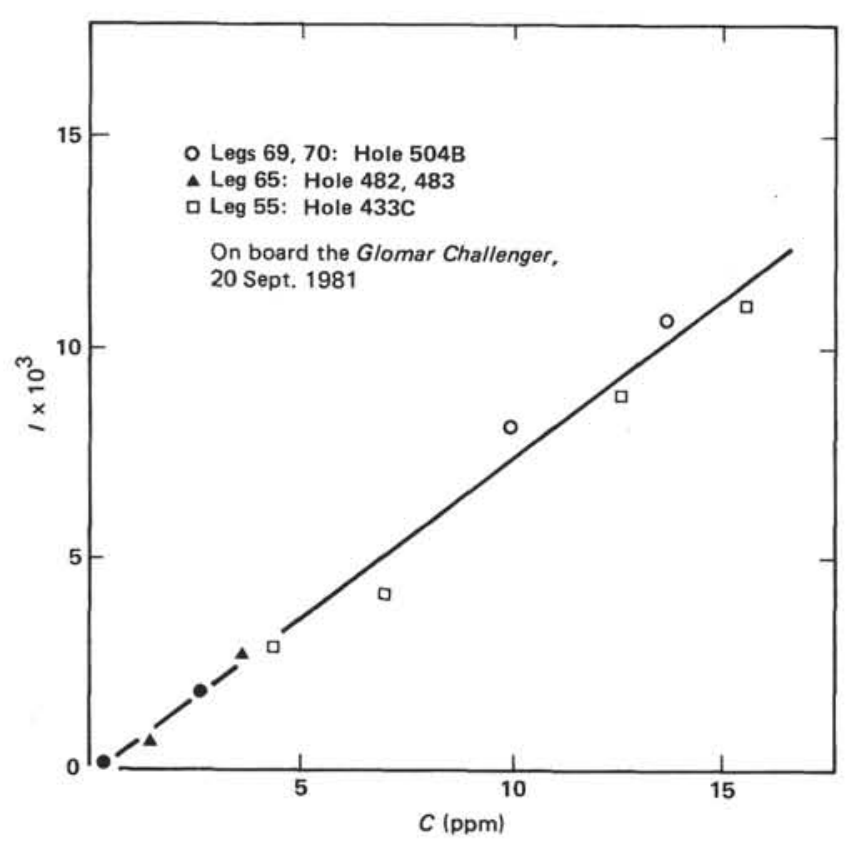

Figure $5 . \mathrm{Nb}$ calibration curve: intensities $(I)$ versus concentration $(C)$.

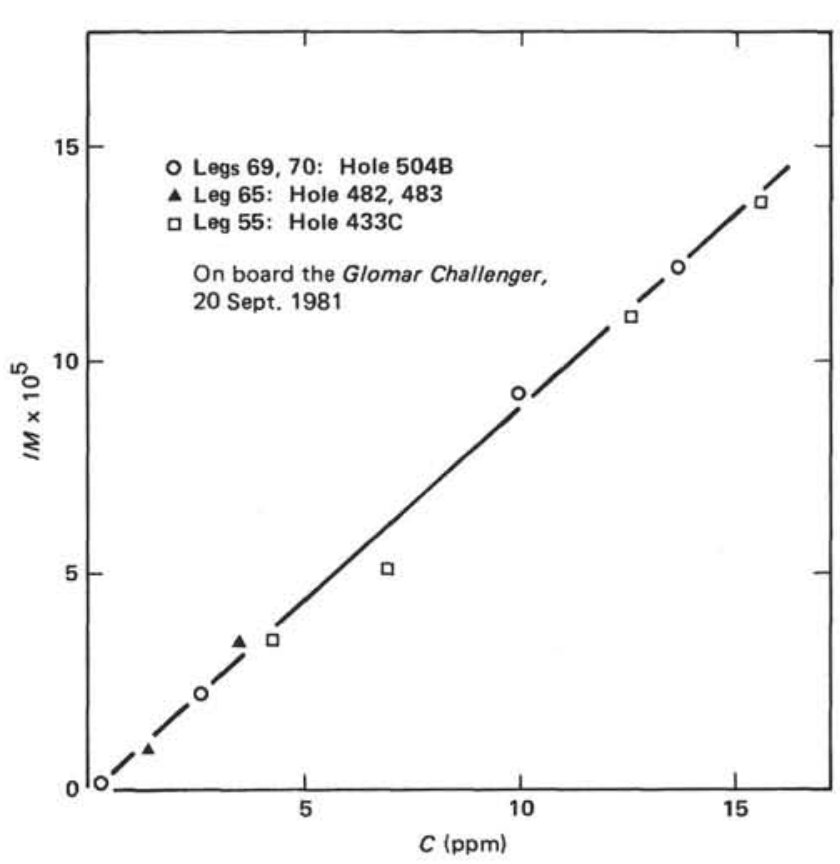

Figure 6. $\mathrm{Nb}$ calibration curve: intensities $(I M)$ (corrected for matrix effects) versus concentration $(C)$.

Table 4. Vanadium: net intensities, matrix-effect values $(M)$, and recommended and calculated concentrations of standards.

\begin{tabular}{|c|c|c|c|c|c|}
\hline Standard & Intensity & $M$ & $\begin{array}{l}\text { Recommended } \\
\text { concentration } \\
\text { (ppm) } \\
\text { V }\end{array}$ & $\begin{array}{l}\text { Interfering } \\
\text { element: } \\
\text { recommended } \\
\text { concentration } \\
\mathrm{Ti}\end{array}$ & $\begin{array}{c}\text { Calculated } \\
\text { concentration } \\
\text { (ppm) } \\
\mathrm{V}\end{array}$ \\
\hline $\mathrm{BCR}_{1}$ & 37,464 & 289.68 & 410 & 13,320 & 410 \\
\hline $\mathrm{PCC}_{1}$ & 3109 & 226.28 & 31 & 60 & 33 \\
\hline DTS $_{1}$ & 1306 & 222.06 & 9.5 & 60 & 8 \\
\hline $\mathrm{GSP}_{1}$ & 7141 & 284.71 & 49 & 3960 & 47 \\
\hline $\mathrm{AGV}_{1}$ & 13,768 & 282.15 & 118 & 6300 & 117 \\
\hline GA & 5105 & 278.11 & 36 & 2280 & 40 \\
\hline GH & 1087 & 274.04 & 5 & 480 & 4 \\
\hline BR & 26,943 & 324.30 & 244 & 15,660 & 245 \\
\hline DRN & 19,864 & 287.66 & 221 & 6600 & 221 \\
\hline
\end{tabular}

Note: $\left(I-I_{0}\right) M=A C+A^{\prime} C^{\prime}+B . A=16,765.99 ; A^{\prime}=292.88 ; B=$ $332,599.72 ; I_{0}=-877.17$. (See text for discussion.) Tube, Au; flow counter; collimator, $0^{\circ} 15$; crystal, LIF; vacuum; background counting time, $40 \mathrm{~s}$; peak counting time, $2 \times 40 \mathrm{~s} ; 2 \sigma$ left background, $76^{\circ} 00^{\prime} ; 2 \sigma$ right background, $78^{\circ} 20^{\prime} ; 2 \sigma$ peak, $76^{\circ} 98^{\prime}$.

The stability of the instrument and the variation of calculated concentrations can also be evaluated in Figure 7. On this figure, the calculated $\mathrm{Nb}$ concentrations of the lowest (Leg 69: Sample 504B-4-2, 52-58 cm, $0.3 \mathrm{ppm}$ ) and the highest (Leg 55: Sample 433C-14-3, $55-57 \mathrm{~cm}, 15.3 \mathrm{ppm}$ ) standard are plotted versus time: 21 measurements for the highest standard and 25 measurements for the lowest, made on different days during Leg 82. The standard deviation calculated from both standards $(\cong 0.7 \mathrm{ppm})$ is consistent with the standard deviation from the calibration curve itself in Figure 6. This standard deviation represents one determination; repeated measurements of the same sample or of samples belonging to the same magmatic unit improve the precision. During Leg 82, two to about ten samples were analyzed for a given basalt unit; this gives a better precision than the standard deviation mentioned above. We 


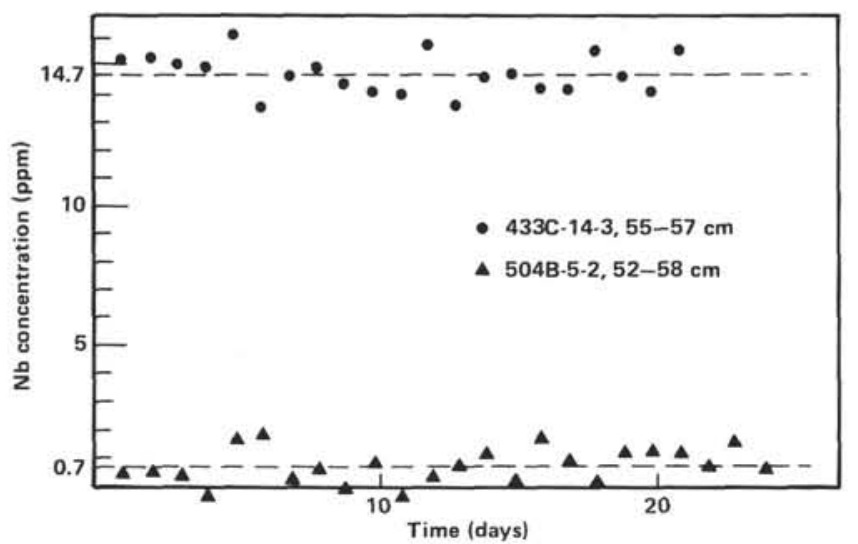

Figure 7. Calculated $\mathrm{Nb}$ concentration of the lowest standard (Leg 69, Sample 504B-4-2, 52-58 cm: $0.3 \mathrm{ppm}$ ) and the highest standard (Leg 55, Sample 433C-14-3, 55-57 cm: $15.3 \mathrm{ppm}$ ) versus time as the cruise progressed.

will consider that the $\mathrm{Nb}$ concentration of each basalt unit is known with an accuracy of between 0.8 and $0.3 \mathrm{ppm}$, according to the number of samples analyzed per unit.

Verification of the shipboard $\mathrm{Nb}$ measurements lies in the comparison to onshore INAA for Ta performed by J. L. Joron at "Laboratoire P. Sue du CNRS Saclay," because it has been well demonstrated that the $\mathrm{Nb} / \mathrm{Ta}$ ratio is constant. $\mathrm{Nb}$ concentrations determined aboard ship are plotted versus these Ta concentrations in Figures 8 and 9 . Figure 9 enlarges the area enclosed by dashed lines in Figure 8 ( $\mathrm{Nb}$ varying between 0 and 10 $\mathrm{ppm})$. The $\mathrm{Nb} / \mathrm{Ta}$ ratio of 16 is well confirmed, and the dispersion of points around the straight lines of Figures 8 and 9 demonstrates that the $\mathrm{Nb}$ accuracy is better than the $0.8 \mathrm{ppm}$ just mentioned.

Figure 10 is an example of interpreted data combining shipboard data ( $\mathrm{Nb}, \mathrm{Zr}, \mathrm{Ti}, \mathrm{Y}$, and $\mathrm{V}$ ) and onshore INAA data (Th, Ta, $\mathrm{La}, \mathrm{Hf}, \mathrm{Tb})$. On the ordinate it represents the logarithm of the element concentration normalized to chondrites (Bougault et al., this volume) versus, on the abscissa, the (decreasing) values of hygromagmaphile character of the elements (Th to V). For $\mathrm{Nb}$, the value 10 represents $5 \mathrm{ppm}$; because the objective of on-board analyses was to detect enriched and depleted samples, it is easy to understand why we had to be very cautious in measuring $\mathrm{Nb}$ concentrations.

\section{CONCLUSION}

The strategy for conducting Leg 82 was largely based on geochemical results that could be obtained on board the ship. The elements of interest, those that make possible identification of so-called "enriched" or "depleted" basalts, and whose concentrations could be measured by XRF spectrometry on board, are trace elements, with ranges of concentration between 0 and $300 \mathrm{ppm}$. A special case is represented by $\mathrm{Nb}$, because its concentration is low in basalts (most of the values are between 0 and $15 \mathrm{ppm}$ ), and it can be considered a key element in deducing the "enrichment" or "depletion." Special care was taken in analyzing for this element, both to improve the statistics and to minimize the possible systematic errors.



Figure $8 . \mathrm{Nb}$ concentration (shipboard determination) versus Ta concentrations (on-shore determination). The different symbols stand for the individual Leg 82 sites.

Shipboard $\mathrm{Nb}$ measurements have been verified on shore through Ta INAA, taking advantage of the constant $\mathrm{Nb} / \mathrm{Ta}$ ratio in basalts. It has been proven that the accuracy of $\mathrm{Nb}$ concentration in each basalt unit as determined on board is better than $1 \mathrm{ppm}$. The accuracy depends upon the number of analyzed samples per basalt unit; a good estimate is $0.5 \mathrm{ppm}$.

\section{ACKNOWLEDGMENTS}

We are grateful to CNEXO, CNRS, and DGRST, the French agencies that funded the XRF van and that, together with DSDP, made use of it possible during Leg 82 .

\section{REFERENCES}

Abbey, S., 1980. Studies in "standard samples" for use in the general analysis of silicate rocks and minerals. Geostandards Newslett., 4(2):163-190.

Andermann, G., and Kemp, J. W., 1958. Scattered X-rays as internal standards in X-ray emission spectroscopy. Anal. Chem., 30: 1306-1309.

Bougault, H., 1977. Major elements: analytical chemistry on board and preliminary results. In Aumento, F., Melson, W. G., et al., Init. Repts. DSDP, 37: Washington (U.S. Govt. Printing Office), 643-652.

1980. Contribution des éléments de transition à la compréhension de la génèse des basaltes océaniques. Analyse des éléments traces dans les roches par spectrométrie de fluorescence $\mathrm{X}$ [thèse]. Université Paris.

Bougault, H., and Cambon, P., 1973. Dispersive X-ray fluorescence analysis on board oceanographic vessels. Mar. Geol., 15:37-41. 
Bougault, H., Cambon, P., and Toulhouat, H., 1977. X-ray spectrometric analysis of trace elements in rocks-correction for instrumental interferences. X-Ray Spectrom., 6(2):66-72.

Bougault, H., Joron, J. L., and Treuil, M., 1979. Alteration, fractional crystallization, partial melting, mantle properties from trace elements in basalts recovered in the North Atlantic. In Talwani, M., Harrison, C. G., and Hayes, D. E. (Eds.), Deep Drilling Results in the Atlantic Ocean: Ocean Crust: Washington (Am. Geophys. Union), Maurice Ewing Series, 2:352-368.

Bougault, H., Treuil, M., and Joron, J. L., 1979. Trace elements in basalts from $23^{\circ} \mathrm{N}$ and $36^{\circ} \mathrm{N}$ in the Atlantic Ocean: fractional crystallization, partial melting, and heterogeneity of the upper mantle. In Melson, W. G., Rabinowitz, P. D., et al., Init. Repts. DSDP, 45: Washington (U.S. Govt. Printing Office), 493-506.

Cambon, P., Joron, J. L., Bougault, H., and Treuil, M., 1980. Emperor seamounts, trace elements in transitional tholeiites, alkali basalts and hawaiites: mantle homogeneity or heterogeneity and magmatic processes. In Jackson, E. D., Koizumi, I., et al., Init. Repts. DSDP, 55: Washington (U.S. Govt. Printing Office), 585-597.

1983. Leg 65: East Pacific Rise-typical oceanic crust depleted in hydromagmaphile elements. In Lewis, B. T. R., Robinson, P., et al., Init. Repts. DSDP, 65: Washington (U.S. Govt. Printing Office), 623-634.

Champion, K. P., Taylor, J. C., and Wittem, R. N., 1960. Rapid X-ray fluorescence determination of traces of strontium in samples of biological and geologic origin. Anal. Chem., 38(1):109-112.

Clark, N. H., and Mitchell, R. J., 1972. Scattered primary radiation as an internal standard in X-ray emission spectrometry use in the analysis of copper metallurgical products. X-Ray Spectrom., 2: 47-55.

Cullen, T. J., 1962. Coherent scattered radiation: internal standardization in X-ray spectrometric analysis of solutions. Anal. Chem., 34(7):812-814.

Delong, S. E., and McCullough, D., 1973. Compton scattered tungsten X-rays as a measure of mass absorption coefficients in rocks. Am. Mineral., 58:1073-1075.

El Azzouzi, M., 1981. Géochimie comparée de quelques éléments hygromagmaphiles dans les roches volcaniques de contextes géodynamiques variés [thèse]. Université de Bretagne Occidentale, Bretagne, France.

El Azzouzi, M., Bougault, H., Maury, R., and Villemant, B., 1982. Application du diagramme de Coryell-Masuda "élargi" à l'étude du fractionnement du titane et du vanadium dans la série alcaline de la chaîne des Puys. C. R. Hebd. Acad. Sci. Paris, Ser. 2, 295: $1117-1120$

Etoubleau, J., Corre, O., Joron, J. L., Bougault, H., and Treuil, M., 1983. Costa Rica Rift: Variably depleted basalts in the same hole. In Cann, J. R., Langseth, M. G., Honnorez, J., Von Herzen, R. P., White, S. M., Init. Repts. DSDP, 69: Washington (U.S. Govt. Printing Office), 765-773.

Feather, C. E., and Willis, J. P., 1976. A simple method for background and matrix correction of spectral peaks in trace element determination by X-ray fluorescence spectrometry. X-Ray Spectrom., 5:41-48.

Hower, J., 1959. Matrix corrections in the X-ray spectrographic trace element analysis of rocks and minerals. Am. Mineral., 44:19-32.

Hutton, J. T., and Norrish, K., 1977. Plant analyses by X-ray spectrometry. II. Elements of atomic number greater than 20. X-Ray Spectrom., 6(1):12-17.

Jaffrezic, H., Joron, J. L., and Treuil, M., 1977. Trace element determination in rock powder. A study of the precision for a given ana- lytical procedure: instrumental epithermal neutron activation. $J$. Radioanal. Chem., 39:185-188.

Johnson, C. M., and Stout, P. R., 1958. Fluorescent X-ray spectrometry, interferences from Compton scattering from matrices of low atomic number. Anal. Chem., 30:1921.

Kalman, Z. H., and Heller, L., 1962. Theoretical study of X-ray fluorescent determination of trace of heavy elements in light matrix. Anal. Chem., 34:946-951.

Leoni, L., and Saitta, M., 1977. Matrix effect corrections by $\mathrm{Ag} \mathrm{K} \alpha$ Compton scattered radiation in the analysis of rock sample for trace elements. $X$-Ray Spectrom., 6:181-186.

Leroux, J., and Thinh, T. P., 1977. Tables revisées des coefficients d'absorption massique des rayons X: Quebec, Canada (Corporation Scientifique Claisse).

Natland, J., Bougault, H., Fujii, T., Graham, A. L., Melson, W. G. Prosser, E., Rhodes, J. M., and Zolotarev, B., 1979. Chemical data for Sites 395 and 396: analytical procedures and comparison of interlaboratory standards. In Melson, W. G., Rabinowitz, P. D., et al., Init. Repts. DSDP, 45: Washington (U.S. Govt. Printing Office), 681-705.

Nesbit, R. W., Haskins, H., Stolz, G. W., and Bruce, D. R., 1976. Matrix corrections in trace element analysis by X-ray fluorescence: an extension of the Compton scattering technique to long wavelengths. Chem. Geol., 18:203-213.

Price, N. B., and Angell, G. R., 1968. Determination of minor elements in rocks by thin film X-ray fluorescence techniques. Anal. Chem., 40(3):660-663.

Quintin, M., 1970. Utilisation de la fluorescence X pour l'analyse non destructive des éléments en traces de numéro atomique supérieur à 27 dans les roches silicatées, bauxites et carbonates. Colloque Int. CNRS (Nancy, 1968), 923:75-86.

Reynolds, R. C., 1963. Matrix correction in trace element analysis by $\mathrm{X}$-ray fluorescence. Estimation of the mass absorption coefficient by Compton scattering. Am. Mineral., 48:1133-1143.

1967. Estimation of mass absorption coefficient by Compton scattering: improvements and extensions of the method. Am. Mineral., 52:1493-1502.

Schilling, J.-G., and Winchester, J. W., 1967. Rare earth fractionation and magmatic processes. In Runcorn, S. K. (Ed.), Mantles of the Earth and Terrestrial Planets: New York (Interscience), pp. 267-283.

Sherman, J., 1955. Theoretical derivation of fluorescent X-ray intensities from mixtures. Spectrochim. Acta, 7:283.

Verdumen, E. A. T. H., 1977. Accuracy of X-ray fluorescence spectrometric determination of $\mathrm{Rb}$ and $\mathrm{Sr}$ concentrations in rock samples. $X$-Ray Spectrom., 6(3):117-122.

Walker, D., 1973. Behavior of X-ray mass absorption coefficients near absorption edges: Reynold's method revisited. Am. Mineral., 58: 1069-1072.

Weber, G. K., and Newbury, M. L., 1971. X-ray fluorescence determination of minor and trace elements in silicate rocks. Can. Spectrosc., 90-91.

Wilband, J. T., 1975. Rapid method for background corrections in trace element analysis by X-ray fluorescence: an extension of Reynold's method. Am. Mineral., 60:320-323.

Wyrobisch, W., 1977. Comparison of two background correction procedures for X-ray fluorescence trace element analysis of some standard samples. Geostandards Newslett., 1:107-110.

Date of Initial Receipt: 1 August 1983

Date of Acceptance: 22 December 1983 


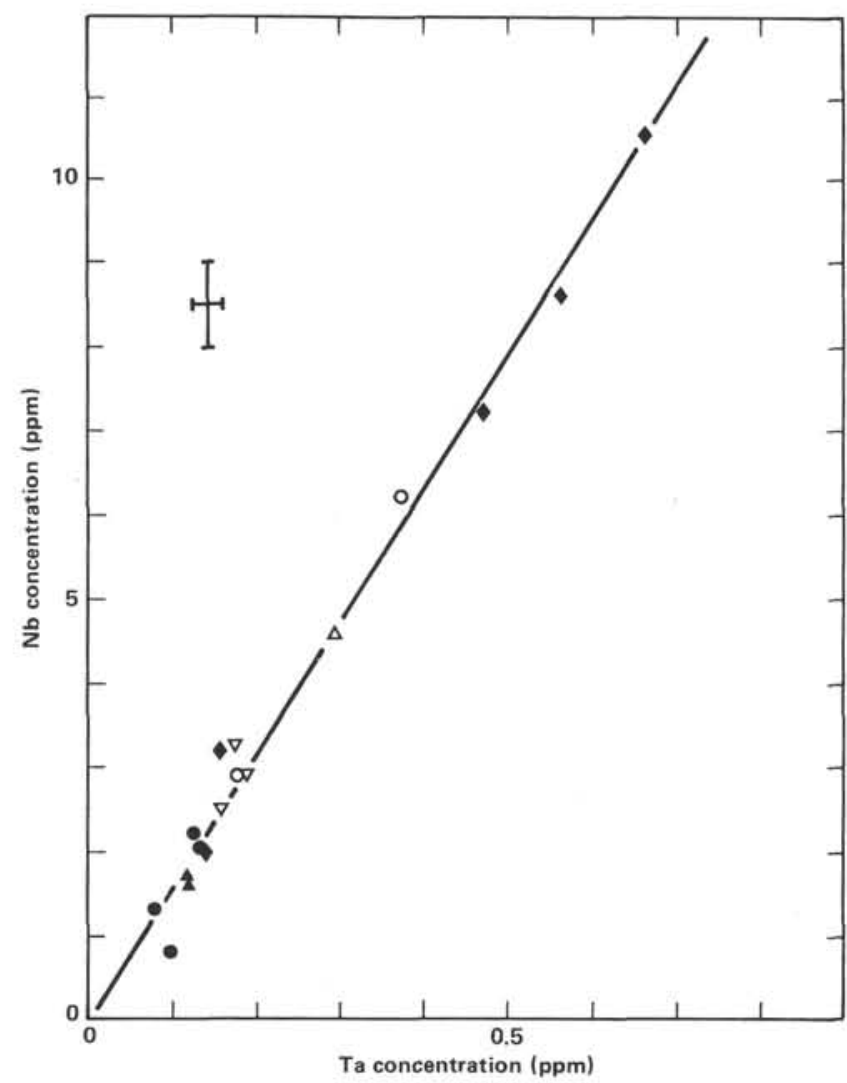

Figure 9. $\mathrm{Nb}$ versus Ta concentrations: enlargement of the area within the dashed lines on Figure 8. Symbols as in Figure 8; cross indicates theoretical precision.

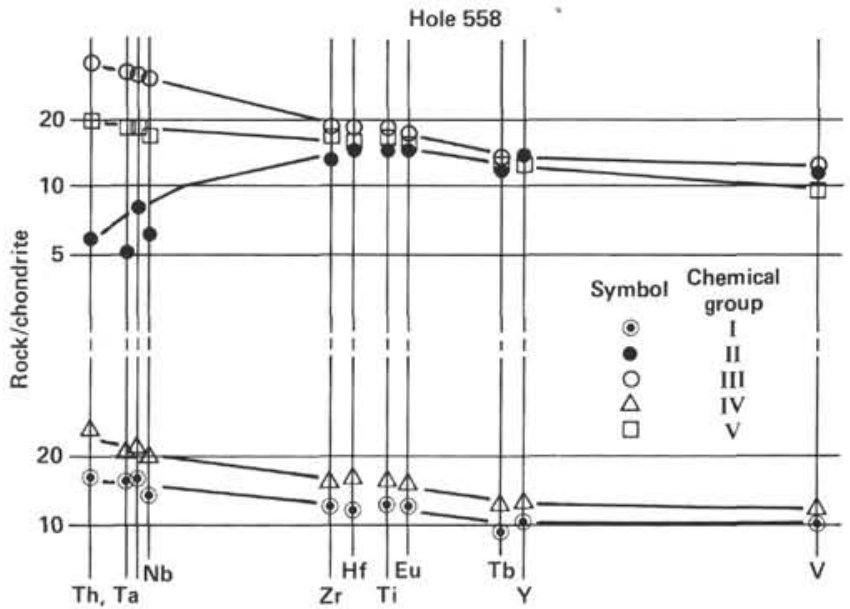

Figure 10. Extended Coryell-Masuda plot obtained for Site 558. On the $Y$ axis is plotted the logarithm of the concentrations normalized to chondrite concentrations. On the $X$ axis the elements are positioned according to their affinity for the liquid phase of the magma, on a scale defined by the continuous variation of this property of rare earth elements. 